\title{
READING THE MUSEUM ANGKUT: CULTURAL SPACE PRODUCTION AND EXHIBITION NARRATIVE
}

\author{
Nindyo Budi Kumoro, Irsyad Martias, Manggala Ismanto, Hipolitus K. Kewuel, \\ Andi A. Saifullah, and Jihananda M. Egidyah
}

Prodi Antropologi, Fakultas Ilmu Budaya, Universitas Brawijaya, Jl. Veteran No. 1 Malang, 65145

E-mail: doni.kumoro@ub.ac.id; im84@ub.ac.id; manggala@ub.ac.id; hipopegan@ub.ac.id

\begin{abstract}
This article is a museum study from an anthropological perspective. Generally, the museum is an institution that stores and preserves particular material cultures. On the other side, a museum can also be critically seen as a space for the production of cultural discourse that narrates a particular ideology through exhibition strategies and display systems. This study wants to explore the discourse of cultural ideology that is represented by the museum through the design and exhibition. The museum is no longer only monopolized by the state but also developed by the private sector which offers a fusion model between the museum, edutainment, and amusement park. Thus, this article proposes a case study of the Museum Angkut in Batu, East Java, one of the most popular private museums in Indonesia that exhibits transportation system and world civilization themes assembled by implementing amusement park concepts. This article would like to address the issue of the production of cultural discourse. The research questions are what kind of cultural discourse production is narrated in the Museum Angkut, and how has it been materialized through the display strategy? Additionally, this article explores the relationship of the visitor with material objects in the museum. This paper uses a hermeneutic approach, and Michael Foucault's heterotopia to examine how cultural imagination with its ideology is represented in museum bodies. As a result, we argue that the Museum Angkut can reflect the character of society, as a post-colonial nation in the sense of seeing self and other cultures.
\end{abstract}

Keywords: Museum; other; cultural space; exhibition

\section{MEMBACA MUSEUM ANGKUT: PRODUKSI RUANG KULTURAL DAN NARASI EKSHIBISI}

\begin{abstract}
ABSTRAK. Tulisan ini adalah kajian tentang permuseuman dari sudut pandang antropologi. Museum merupakan institusi yang disamping menyimpan objek budaya material, juga sebagai ruang produksi wacana budaya melalui strategi pameran (ekshibisi) maupun tata pajangnya (display). Penelitian ini ingin menelusuri wacana ideologi budaya yang terepresentasikan dari museum melalui perancangan dan tata pajang yang disajikan. Museum saat ini tidak lagi hanya dimonopoli oleh negara, tetapi juga dikembangkan oleh sektor privat yang menghadirkan penggabungan antara museum, edutainment maupun amusement park. Dalam konteks tersebut, tulisan ini mengajukan studi kasus Museum Angkut di Batu, Jawa Timur, sebagai salah satu museum swasta populer di Indonesia yang mengusung tema transportasi dunia dan peradaban dunia tersohor yang dikemas dalam konsep amusement park. Tulisan ini berupaya menjawab persoalan tentang produksi wacana budaya seperti apa yang dinarasikan dalam Museum Angkut dan bagaimana hal tersebut diwujudkan melalui strategi tata pajangnya? Selain itu, artikel ini berupaya melihat relasi pengunjung dengan benda material dalam museum. Untuk mengungkap persoalan tersebut, peneliti menggunakan pendekatan hermeneutik dan sudut pandang heterotopia Michael Foucault, yang mengulas bagaimana imajinasi budaya direpresentasikan dalam sebuah tubuh museum. Hasilnya, kami berpendapat bahwa Museum Angkut dapat menjadi representasi bagaimana museum mencerminkan karakter masyarakat sebagai bangsa pascakolonial dalam hubungannya melihat diri sendiri dan kebudayaan liyan.
\end{abstract}

Kata kunci: Museum; liyan; ruang kultural; ekshibisi

\section{INTRODUCTION}

Generally, the museum is an institution that stores and preserves particular material cultures. Also, the museum can be defined as a space that tacitly contains cultural knowledge. As a cultural space, a museum can also be seen as a space for the production of cultural discourse that narrates a particular ideology with social, political, and economic purposes through exhibition strategies and display systems (Hall, 2003: 5; Lidchi, 1997: 168; Marsanto, 2012: 44; Svašek, 2007: 137). Cultural ideologies that appear in museums commonly represent power relations which had been occurred in particular eras (Clifford, 1985: 240; Hooper-Greenhill, 1992: 168). For instance, in the early period of the emergence of museum practices in Europe -from middle age to 19th century- the museums were designed by nobles or scientists for exhibiting 'strange' or 'unique' artifacts. In other words, the museum can be said as a cabinet of curiosity (Koentjaraningrat, 1980: 14). Furthermore, those artifacts are mostly originated from communities outside Europe that were carried out from explorations, trade expeditions, and colonializations. Constructed by the European perspective, these cultural artifacts are narrated as a symbol of primitiveness and others or exotic cultures (Svašek, 2007: 215).

The phenomenon of museums in Indonesia during the colonial era also followed the European trend, which focused on the indigeneity, especially ethnographic, archaeological, and historical objects (Rath, 1997: 7; Taylor, 1995: 107). However, the fashion of museums as a place for "recognizing others" has begun shifting since the independence era. Then, the museum has been used as a political tool to narrate and construct the national identity 
and the national imagination (Anderson, 1991: 178; Taylor, 1995: 110). In this post-colonial period, museums that are popular in Indonesia are related to the history of nationalism, militarism, local kingdoms, prominent figures, and local cultures in order to "identify themselves" as a nation (McGregor, 2003: 107).

This article wants to tell how the museum, as a space for the production of certain cultural narratives in Indonesia today, has developed, predominantly since in the reformation era within the escalation of global culture. In other words, the story telling of the museum today has been hybridized between a cultural space and the amusement park, in response to the massive growth of the mass tourism industry, the development of urban lifestyle and consumerism, and the privatization of the museum as a business entity (Balloffet et al., 2014: 4). Along with the development of the contemporary museum, (Balloffet et al., 2014: 9) state that we can no longer give a strict definition between museums and amusement parks (or theme parks) because both emphasize the implementation of architectural designs, entertainments, the interactive technology, and visitor experiences. It differs from the previous museum understanding, which is merely a place of collected artifacts (Macdonald, 2003: 5; Rectanus, 2006: 390; Wardoyo \& Zef, 2020: 73).

In Indonesia, the shift of museum practices can be seen from the birth of private museums that offers edutainment and fascinating architectural concepts, adopting the famous Disney Land (Nuffida et al., 2016: 55). In the context of "Disneyfication" and the space of cultural production and exhibition narrative, the museum is no longer oriented to construct local and national identity, but the museum has become a space for popular and global culture productions (Rectanus, 2006: 383).

To illustrate the new museum trends in Indonesia and as our case study, this research takes place at the Museum Angkut (Transportation Museum), Batu City, East Java. The museum was founded in 2014 by Jawa Timur Park Group, a holding company that manages a variety of amusement parks in Indonesia. Although this place superficially appears to be a recreational park or an amusement park, the Museum Angkut has a strong character as a cultural museum by displaying a hundred collections of vehicles and means of transportation from different countries, civilizations, and periods. Moreover, the existence of the Museum Angkut, as a representation of museums in Indonesia nowadays, can be legitimized by two reasons. First, the Museum Angkut is considered as the best museum among many other museums in Indonesia, according to the government ${ }^{1)}$. Also, it has been registered by the Indonesian Museum Association (Asosiasi Museum Indonesia, n.d.). Second, this museum is one of the few museums in Indonesia that has the highest number of visitors. In other words, we can say that how people are enthusiastic about this cultural space so much! ${ }^{2)}$
In the context of the museum as a space for the production of cultural discourse, the Museum Angkut narrates exhibitions that are quite different from the other conventional museums in Indonesia, both in terms of collections and its nuances. Hundreds of collections of transportation from various countries and periods are placed in buildings with a fascinating architectural design and interactive media. Thus, the interplay of those elements may manipulatively bring the visitors to be in other places where particular vehicles came from, such as The United States of America, Italy, France, Germany, and England. According to museum management, transportation is a part of cultural products that can represent civilization, spatially, and temporally, so displaying collections in a conventional way is insufficient. As mentioned on its website, "it is necessary to revive the function and identity of each vehicle and placing it inside rooms that are made authentic to the specific period and places" (Jawa Timur Park Group, 2017). This phrase can be interpreted as the Museum Angkut effort to "transport" certain cultural civilizations (especially Western Europe) as the main attraction for visitors.

Based on the explanation above, this article wants to reveal that the Museum Angkut is functioning as a place of knowledge of the other, more specifically in the frame of global popular cultures. Therefore, research questions that need to be investigated are what kind of cultural discourse production is narrated in the Museum Angkut, and how has it been materialized through the display strategy? Thus, this paper examines two problems. First is related ideation of the Museum Angkut. Second is related to the response of visitors in interpreting the exhibition's narrative. Also, by correlating those questions, this research wants to bring the readers to understand that the Museum Angkut, as a contemporary museum in Indonesia, can reflect the character of a post-colonial society in the case of seeing self and other cultures.

\section{METHOD}

This study interprets the production of cultural space and the narrative behind the display. Thus, the hermeneutic approach is felt to be most appropriate by interpreting cultural practices as a text or language that can be "read" to gain a certain understanding (Geertz, 1992: 5). In other words, museums and exhibitions can be treated as texts that transmit not only explicit information but also certain symbolic meanings or hidden messages relating to the knowledge system or cultural ideology orientation of its constituent units, as mentioned by Stuart Hall (Marsanto, 2012: 8);

"We can say that all these practices 'work like language', not because they are all written or spoken (because they are not), but because they all use some element to stand for or represent what they want to say, to express or communicate thougt, concept, idea or feeling. Exhibition or display in museum or gallery 
can also be thougt of as 'like a language' since it uses objects on display to produce certain meanings about the subject-matter of the exhibition."

Through this framework, we implemented a qualitative research method by emphasizing on participant observation in order to know how the museum communicates with visitors through display systems. The display system is related to how the museum (1) selects and (2) classifies the collection, (3) how to display the objects, (4) how to describe them, (5) how to direct visitors in the museum circuit (6) and the ways of creating spaces and other signs. In other words, the form of communication between visitors and museum elements can be seen from how the responses and behavior of the visitors in interpreting the messages conveyed by the museum. Data collection was carried out in June 2018. We made observations on weekend days (during peak season). In total, we made eight visits.

In order to construct intersubjective data; indepth interviews were also conducted to gain information from a curator and visitors. We interviewed ten informants whom we found based on clues from participant observation activities. In general, the social backgrounds of the informants are university and school students, employees, businesspersons. Most of them visited as a group of tourist trips, families, and couples.

The secondary data were taken from literature reviews, books, journals, news in the mass media, including museum brochures. We implement a heterotopia (space) theoretical lens in analyzing or interpreting the data. Heterotopia (space) is a place where "utopia" or illusory thing is expressed, contested, distorted, and then materialized (Foucault \& Miskowiec, 2012: 3). We use this idea in evaluating spatial arrangements of the Museum Angkut, which are manifested by the representation of western ideology with its material cultures. In other words, there are fragments of time, culture, and place displayed that are solidified in singular space. In short, in this museum, there are representations of western culture, such as a classical Buckingham Palace, retro Texas-style car garages, and the landmark of European cities.

In this study, there are two principles of heterotopia that are interconnected; the first principle is an explanation of the placement of spaces of different cultural mimeses in the same place. Second, the principle is related to the accumulation of time which never stops building the story (Foucault \& Miskowiec, 2012: 3). These principles of heterotopic events explain what cultural narrative and ideation are imagined and how the process of creating utopic cultural spaces. Furthermore, this concept also helps explain what form of 'knowledge' is represented by the cultural space in the Angkut Museum, especially through its lay-out strategy. The conclusion part will explain the orientation of cultural exhibitions that are lately being preferred by Indonesian people.

\section{RESULTS AND DISCUSSION}

\section{The Ideation of the Museum Angkut}

Covering 11 hectares of land on the hillside, the Museum Angkut is located on Terusan Sultan Agung Street, Batu. This place was founded by the Jawa Timur Park Company (JTP). JTP Group, as a leading recreational company in East Java, manages eleven theme parks where are mostly located in Batu and others in Surabaya, Lamongan, and West Java. Some places have been popular among local tourists such as the Jatim Park 1, Jatim Park 2, Jatim Park 3, BNS (Batu Night Spectacular), Eco Green Park, Wisata Bahari Lamongan (Lamongan Marine Tourism), Maharani Zoo, and Suroboyo Carnival. This company was founded by a business tycoon from Batu, Paul Sastro Sendjojo. Since the beginning of the establishment, JTP has a business vision to develop education-based entertainment tourism (edutainment). This business concept has been implemented, and it became a new paradigm in the museum world since the 1970s. By emphasizing on the implementation of the interactive display, edutainment may give a promising expe-rience to the visitors (Rheingold in Balloffet et al., 2014: 5).

The launch of the Angkut Museum was a result of successful years of Jatim Park 1, 2001-2002, especially during the long Christmas break and new years. Since then, thousands of people enthusiastically visited. The revenue of this business channeled to build the Museum Angkut on March 9, 2014. The Museum Angkut is divided into twelve "zones" with thirty-seven categories of exhibits (vehicles and attractions) that display lots of types of vehicles such as motorcycles, cars, helicopters, bicycles, wagons, miniatures, carts, and miniatures of massive transportations such as planes and public transportations. The museum also offers many attractions such as the costume parade as well as singing and dance shows. Each zone has a specific theme that represents a particular cultural landscape; scenes of cites in Rome, Paris, London, Las Vegas, Luxor in Egypt, Hollywood, Indonesian Chinatown, Malioboro, Batavia, and Banjarmasin Floating Market.

Dwi Cahyono, one of the curators, stated that the ideation of the Museum the Angkut is inseparable from the JTP Group's business goals to offer a recreational place that is not only entertaining but also educating, modern but having cultural contents and happy but serious. These aspects are the fundamental premises to develop JTP flagship amusement parks in their market areas. It also tacitly appears on JTP Group's icon, the Punakawan, figures of Javanese wayang, which has been interpreted by the owner as figures who bring the spirit of warmth, intelligence, and excitement. In other words, like punakawan, as mentioned on its website, JTP Group reminds us, "do not forget to laugh enjoying life in the midst of business!" (Jawa Timur Park Group, 2017) . 
Moreover, the owner, Sastro Sendjojo, is very concerned about the museum and cultural things. For Sastro, the existence of museums in the city and tourist spots is essential, even more for cities which have become a tourist destination like Batu. Thus, the amusement parks created by JTP Group always emphasize museum and art gallery nuances, for instance, Ethnic Gallery (Galeri Etnik) in Jatim Park 1, Animal Museum, Museum of Human Body (Museum Tubuh), Museum Angkut, Indonesian Heritage Museum / Indonesian Mask Museum, and World Music Museum (Museum Musik Dunia) in East Java Park 3.

JTP's museums deliberately want to differentiate themselves from others, by ignoring the rigid format of conventional museums. There is a standard format of exhibitions found throughout Indonesia's (provincial or governmental) museums, one invariably first passes through an area describing natural history and physical geography of a particular region; then main display area about the culture and history, finally there is an area set aside as the 'Ruang Nusantara' where visual comparisons are made between local artifacts and those from elsewhere in Indonesia (Munandar et al., 2011: 2 ; Taylor, 1995: 116). However, Cahyono said that in order to attract more visitors, a museum needs to be packaged in a more entertaining and modern way.

Moreover, JTP's museums are private museums that highly consider profit and loss. Thus, every museum made by JTP Group applies a theme-park concept. The reason why transportation or vehicle, as the main object of the exhibition, also considers market opportunities. Given the fact that there are so many automotive clubs that are bound with many kinds of fashions such as classic, type of car/ motorcycles, brands, and origins. In some extent, a vehicle is not only a means of transportation but also a symbol of social status, identity, and lifestyle. For instance, cars and motorcycles have become icons of contemporary culture and the symbol of global society (Rectanus, 2006: 383). This cultural pattern is translated in the Museum Angkut where displayed vehicles echo the sense of rarity, luxury, uniqueness, valuable, and then those become the "dream and admired goods" of most Indonesian people, especially Europe and American build-up vehicles. ${ }^{3)}$

Automotive enthusiasts are the first segment targeted by the Angkut Museum, but the designers also consider general visitors (non-hobbyists) by offering them exciting attractions. The creation of an attractive atmosphere, as a selling point of the edutainment museum, is an underlying aspect so that the number of visitors is expected to be increasing (Balloffet et al., 2014: 6). Moreover, objects at the museum present with their cultural and environmental context. Thus, it inspires the management to design museum scapes as a museum of the 'civilization', from Indonesian vernacular material cultures, Chinatown, Batavia, America, Europe, even Hollywood, and Las Vegas cityscapes. Even though visitors are not familiar with the automotive world and not intending to find any information about vehicles, they still can enjoy an exciting and entertaining museum atmosphere. Most visitors usually treat the Museum Angkut as objects of photo or selfie, posing-on vehicles, or in front of 'Las Vegas' and 'Hollywood' backgrounds. From the beginning, the idea of nomenclature of this museum was "Museum Angkut and Movie Star Studio," where visitors can feel the sensation of the famous scene of movie settings.

Therefore, visitor's interest then should be materialized into two main features that determine the creative process of the museum scape, which stresses on the representation of vehicles and civilizations. Firstly, in the case of vehicles, the classification of the mode of transportations formulated by the museum management is diverse, starting from; motorized and non-motorized; human or animal tractions; periods; the number of wheels; military, commercial, mass or historic vehicles; land, sea or air transportation, and so on. Secondly, the museum management has inventoried lots of slice of civilizations that have a historical tie with transportations wherein these places and vehicles are also the dream and fantasy for the Indonesian people in general.

However, the cultural selection criteria are based on their popularity or image, which has been embodied in Indonesian people mindset or mentality. In other words, what kind of "dream" can be sold to the visitor? Say it, Western Europe (Britain, France, Germany, Italy) and the United States (Hollywood and Las Vegas) it) with their modernity, or Chinatown (pecinan), Malioboro, Batavia, Sunda Kelapa, and the Banjar Floating Market with their traditionality. So, the mimesis of civilization is a sort of manipulations of decoration and building assemblages that are considered representing strong characteristics of the places; England is represented by the Buckingham Palace, France with the Eiffel Tower, the United States with the Liberty statue and Hollywood, Italy with the Leaning Tower of Pisa, or Sunda Kelapa with its harbor.

In regards to the duplication (or the mimesis) of European civilizations in the museum architecture, (Rectanus, 2006: 391) said that architecture and interior design implementations have become as new and essential elements in the museum project, a magnet to attract visitors by producing global culture discourse. With this representation, the architecture and design of the museum facade have become important factors in creating new relationships between museum visitors and the displayed artifacts (collection). Furthermore, today, the museum show is not only presenting the pieces of the artifacts but also exposing its architectural style. In other words, the museum, as the physical space, has become the object of the exhibition of the museum itself.

\section{Reading the Museum Angkut and its visitors}

We focus on relationships between museums and visitors in order to verify the response of visitors to what the creator of the Museum Angkut has conveyed, 
especially related to the presence of nuances of particular civilizations. Therefore, the essential things that should be analyzed are experiences, responses, and also cultural perspectives undergone by visitors when they were interacting with exhibition spaces in the museum.

From a number of selected informants of the Museum Angkut visitors that we have interviewed, most of them got information about the museum from social media and word-of-mouth marketing, especially for people who live outside Malang. The feed posted on social media such as Facebook, Instagram, and Twitter by visitors attracts other people to visit and feel experiences. The social media vibrant through its network has become an indirect promotion event of the existence of the Museum Angkut.

The experience that is mediated through video uploads and photos on social media is the main reference for (potential) visitors to come to the Transport Museum. Information received by visitors does not come from the web, which is mana-ged directly by the museum but from social media accounts of their friends and colleagues. For example, Heri and Yani, our informants, said that they knew the museum from friends' instastory. The sense of curiosity had crossed after they saw upload contents, especially the background of the photos, such as decorations, facades, attractions, and display objects. The sense of curiosity is expressed into many words "different", "unique", "not as usual/extraordinary", "sophisticated", "modern but classy", "instagrammable", or "too good to miss".

Some other visitors are interested in vehicle exhibitions. Let us say, Robi and Toni, private employees from Malang. These men are persons who understand about the automotive world. Most of the car and motorbike collections displayed are originated from Europe, which also had contributed toward automotive developments in Indonesia. Some visitors felt familiar and they have memories with the vehicles, even though they have never had one. Memories about these vehicles are gotten either from witnessing from the road, magazine, film or television, or being mentioned among automotive enthusiast communities as dream vehicles. These "dream" vehicles are predominantly European or American productions that have become classic or legend cars/bikes, such as Impala, Buick, Cadillac, Mercury Monterey, Mercedes Benz, BMW, Porsche, Ford Mustang, Hummer, Rolls-Royce, and Dodge, and so on. Meanwhile, motorcycle collections that become the center of attention are Euro-America productions such as Harley-Davidson, Triumph, BMW, Norton, Ducati, BSA, and Royal Enfield.

However, some vehicles, either motorbikes or cars, are familiar with visitor's lives, and even more, they have had once, such as Honda, Kawasaki, Toyota, or Suzuki, Vespa, Volkswagen. These types of vehicles are not creating the nuance of fantasy or dream but rather romanticizing the journey of life they have been through with their rides, which then appeared while enjoying the exhibition of the museum. For instance, Budi, a middle class man who visited with his wife and children, said that he got carried away to his past memory when he found the display of a red Honda moped (motor bebek) on the first floor. He said that his father had once. "I have a strong memory, my father always gave me a ride to the school, from junior high school until my sophomore years, and we named it BMW, si Bebek Merah Warnanya (the Red motoped)." Another informant, Jonathan, said that museum collections bring his memory back. He also had the same rides as museum collections, which is a Ford car. He spent much of his time on the exhibition of the Ford car section to reminisce about his memories. "The type of this car was my 18th birthday present from my parents, my car was the red one," he explained.

On the other hand, non-motorized or traditional transportation collections, such as pedicabs, wagons, boats, cycles, and so on, do not significantly impress visitors. According to our informant, besides these vehicles are regularly seen in everyday life, these vehicles are not their interest or fantasy, "not something you want to see," or "not something to take a picture with." "Traditional vehicles are ubiquitous, they are often seen everywhere," Arya said.

However, there is a display of a modern Indonesian sporty car, namely Tucuxi, but the response of visitors to this object is slightly the same as how they experience the collections of other Indonesian transportations, not really attracting. Tucuxi is a prototype of an electric car politically developed by Dahlan Iskan, the Minister of State-Owned Enterprise, 2012, in order to prove that Indonesian human resources are capable of producing electric cars independently. The prototype was test-driven directly by himself, but unfortunately, the test drive encountered a technical failure in the brake system, so it crashed into a hillside in Magetan. The Museum Angkut gets permission to show the crashed car after granting permission from Dahlan Iskan.

Robbi, a university student who is an automotive enthusiast, expressed his sympathy and pride altogether because the car is juxtaposed with built-up cars, "Indonesian people are also able to compete with other countries in the automotive technology, although unfortunately damaged." Another informant, Tonny, said in an ironic tone, "indeed this reflects transportations in Indonesia, most of the things which are displayed are traditional, once displaying a modern and sporty car, the car is crushed like Tucuxi," he said. It seems that it is not too excessive what the informants said, because the vibrant that make them interested in visiting the Museum Angkut is to feel and admire the culture of western automotive technologies, not their own culture or nation.

Moreover, the significant visitor's responses are related to the zoning of civilizations spatially arranged by dividing the world civilization into two sections, EuroAmerican and Indonesian-Asian zones. Based on our observation, it is not difficult to recognize, which is the 
most attractive between those zones. We saw that the most crowded zones that pulled concentrations of visitors (to be used as background photos) are zones such as France, England, Germany, Italy, and also America (Gangster Town and Hollywood). Meanwhile, areas such as the Chinatown, Sunda Kelapa, and Batavia zones are not as vibrant as the western world (see Figure. 1).

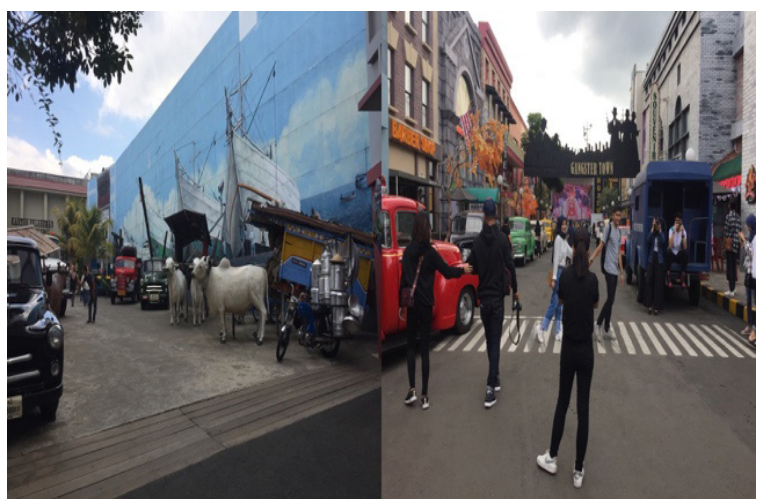

Figure 1. Batavia Zone (left) and Gangster Town (right) Reseachers' photo, 10/10/18

This zone was designed by projecting and miniaturizing western world cityscapes, as mimetic processes. The mimesis is not only in physical terms but also in behavioral aspects that have been demonstrated by visitors. For example, we observed, when visitors were in zones that are stereotypically known as the high culture or civilized such as the United Kingdom or France, visitors pretended to act politely, they strolled, calmness was maintained, took pictures regularly, and so on. However, this behavior is different when visitors were in the United States section, the Gangster Town. This place brings the atmosphere of the mafia city in America that make visitors feel the experience as if they were in the real American city. The image build is a freedom nation, without any hierarchy, is embodied in visitor behaviors. Their behavior becomes cheerful and lively, taking many pictures of fancy poses. In contrast to England and France, as mentioned above, these places are full of politeness, but in the Gangster Town, laughing and screaming are common things that are heard, as if freed from "British feudalism." Likewise, when visitors have arrived at the food court that is designed like a Floating Market (Pasar Apung) as well as the last stop of this museum trip. As like as in their "home" or coming back home from a long journey, visitors in the Floating Market zone were relaxing, lying down, and enjoying some meals. In this case, we would like to highlight that the phenomenon of heterotopia that constructs these mimetic and inverted spaces also influence how visitors behave and interact with museum objects.

Phenomenon above can be understood because the nuance of the duplication of the civilizations is enriched with multi-sensory sensations. This nuance presents not only visual sensations but also audio sensations by tuning music from particular countries as the backsound. The Gangster
Town is placed on open space (outdoor) and accompanied by loud disco music. Meanwhile, the French, with its Eiffel Tower, is built in the vast indoor room, displayed by the arrangement of the sidewalk and calm music. Likewise, the English zone which is represented by Buckingham Palace. The facade of the palace is made as detailed as as possible like the authentic one with the arrangement of the garden that makes visitors as if they were in England. The interior of this palace is full of luxurious royal cars (Roll Royce, Bentley, and Range Rover) that are displayed under gentle spotlights. In this place, there is no loud music, but classical music. More-over, in the middle of this Buckingham Palace hall, there is the Queen Elizabeth mannequin sitting on her throne and escorted by royal guards. Under this situation, especially under the gaze of the 'queen of England,' there is no other way for visitors to behave politely, not to speak aloud, and not forget to take pictures in a "good" manner (See figure 2).

As explained by Milman, (2010: 221), as a tourist attraction, the entertainment offered by the museum is the creation of the fantasy of places and times. The nuance is communicated and reflected by various attributes such as landscapes, architectural styles, costumes, rides, performances, music, and staff who act as actors (Milman, 2010, : 221). Furthermore, Milman (2010: 221) said that nowadays, the museum as an amusement park adopts the uniqueness of intellectual property as the foundation of the theme, such as cultural commodities, landmarks, fictional and non-fictional characters in which these products are very familiar with visitors, but they have had no corporal experiences with them. Therefore, visitors do not just act as spectators, but also as actors in pseudo space.

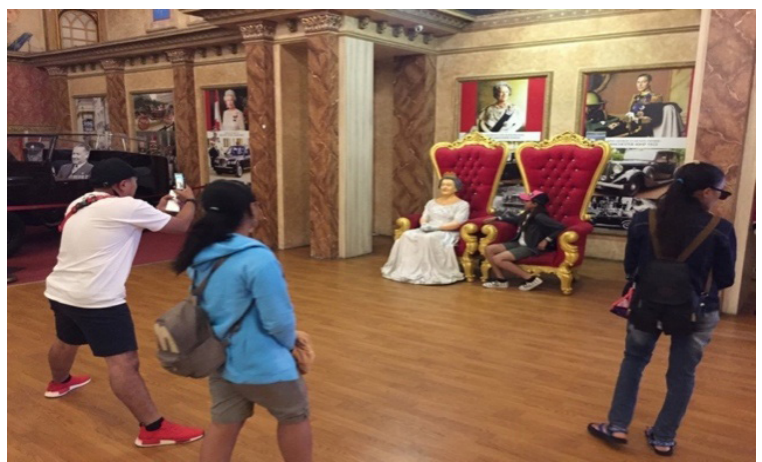

Figure 2. Take a picture with "Queen Elizabeth"

Reseachers' photo, 10/10/18

Visitors also realize about the domination of Western civilization. They feel that the Museum Angkut so attractive because it immensely exposes the representation of western and American cultures and their technologies. The representation of keindonesian (Indonesian-ness) in the museum exhibition is so superficial because it only displays some landscapes represented by the Chinatown (Pecinan), Sunda Kelapa, and Batavia Zones. Ironically, Sunda Kelapa, Chinatown, and Batavia display vehicles from China, the Dutch-Indies (Colonial era), and even more Jeepneys from the Philippines. 
The presence of Indonesian-ness representation displayed in museum zoning tends to subject that the Indonesian culture is traditional, whereas the West is advanced and modern. The animation of technological evolution appears when comparing the eastern represented by Indonesia to the western represented by Europe.

When entering the Indonesian zone, the features of the mode of transportation are dominated by nonmotorized old vehicles, such as pikulan, trishaws, cikar, wagons, and the Majapahit ship. Our informant said that he was not really interested in any traditional things. Besides, this makes visitors feel that what is displayed in the Museum Angkut does not really concern the value of Indonesian-ness, but modernity originated from the Western world. As one informant explained, Braga, "we are in Indonesia, but why do we have very little transportation from our own country? I can count by my fingers." The interaction of visitors with museum displays, which is quite impressive, is the attraction of the cosplay show. On the 3rd floor zone (Runway 27 Airport section), the management involves employees who are assigned to wear clothes such as American superheroes (cosplay) and Air force one pilots. They invite visitors to dance together. The dance shows accompanied by electronic music attract many visitors. Even more, visitors can rent a variety of costumes, for instance, in the Buckingham Palace Garden zone. Even though the renting price is quite high (Rp. $40,000 / 30$ minutes), there are a lot of women (despite wearing headscarves) willing to queue to rent a Western traditional women costume, so that they can take some pictures in the garden as if they are nurturing flowers in a rural European landscape (see figure 3).

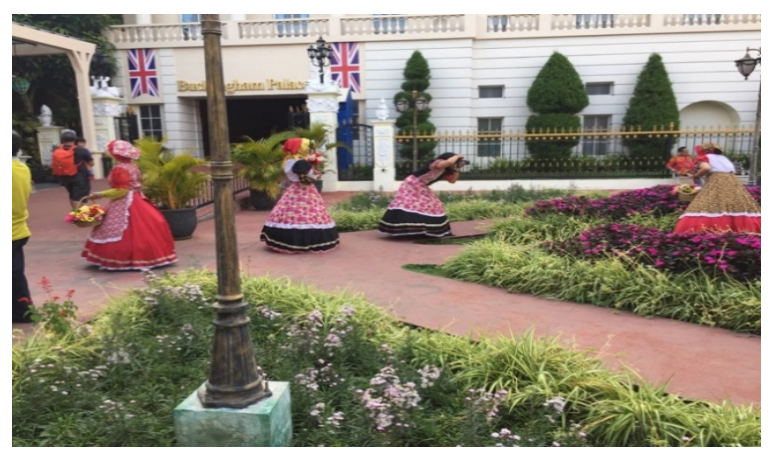

Figure 3. Wearing European folk costume in front of "Buckingham Palace"

Reseachers' photo, $10 / 10 / 18$

By reading the response of visitors to the Museum Angkut exhibitions, we can understand that this museum is not a place to gain educative information like most museums. The "having fun" activities demonstrated by most visitors create this museum as a fascinating photo studio. Visitors not only capture the uniqueness of the exhibition alone but also present themselves in the photographs with a variety of backgrounds. The goal is simple, to save memories or to show off through social media, as the evidence that they have been in other "space and time." However, some background objects of the photograph are ubiquitous where people can see without having to go to the Museum Angkut. For instance, some visitors took pictures in front of; the dining table, the house fence, traditional market carts, a Vespa, as well as posing on the zebra crossing in Gangster Town. Nevertheless, the imagination of visitors in the context of "the heterotopia," makes the ordinary places turn to be another meaning. In this case, being in the Museum Angkut is the "another" world and time, creating "usual" becomes "unusual."

As explained by Crosby (2016: 5), a museum is a cultural space that has the power to turn visitors or audiences to be actors. By paraphrasing Victor Turner, Crosby stated that the process of transition of the audiences into actors that are signified by the visitor and the museum object interactions that can be defined as a process of liminality and ritualization of post-modern society. The liminality is an ambiguity of "between and betwixt" experienced by people or groups when they become "the other" in a momentary time. In this case, when visitors are in the museum circuit, they have been exposed to a blending of modern and traditional symbols, the domination of the west over the east, and the prin-ciple of alienation and community, which stimu-lates the experience of visitors to become "the other."

\section{CONCLUSION}

The reading of the Museum Angkut exhibition narrative above shows that there are new museum trends that occur in post-reform Indonesia within the escalation of global culture. Cultural ideology produced in the museum exhibition narrative is significantly different from the era of the cabinet of curiosity or self-introduction that had been implemented in the past regimes. Nowadays, the museum paradigm emphasizes entertainments, amusement park concepts, and produces popular culture discourses. In addition, as a private museum, the ideation of producing popular cultural discourse and the exhibition narrative in the Museum Angkut is strongly driven by business interests in the tourism industry (market ideology). This phenomenon is similar to the "boom" of the blockbuster museum phenomenon in the United States in the 1970s, as an indication of integration between museums with the entertainment and tourism industry (Bradburne, 2001: 76). The ideology above constructs the narrative pattern of the Museum Angkut exhibition, starting from the selection of museum themes, display strategies, architectural styles, and attractions. The themes of transportation and architectural styles are dominated by the discourse of global culture originated from European and American cultures and civilizations. Although the modes of transportation and Indonesian cultural landscapes, as the representation of Indonesian cultures or civilizations, have been presented, those are narrated as traditional elements that are less dominant and undesirable. European and American civilization attractions displayed in the Museum Angkut 
are much more attractive to visitors, from dressing up to be European ladies in the British section and posing cool styles in the American Gangster Town and admiring the dream cars. In this sense, the Museum Angkut becomes a heterotopia (space) (Foucault \& Miskowiec, 2012) where the cultural imagination of space and the sense of the otherness are manifested into physical forms and produced altogether with the museum and visitors. Lastly, the Museum Angkut, as a popular museum in Indonesia, can present how the museum may reflect the character of society, as a post-colonial nation in sense of seeing self and other cultures.

\section{ACKNOWLEDGMENTS}

This research was made possible by the Education Development Fund grant (DPP/SPP) Faculty of Cultural Sciences, Brawijaya University, we received in 2018. We are deeply indebted to Dwi Cahyono (Universitas Negeri Malang) for his museum information and Museum Angkut staff for giving a permit to this research to be carried out.

\section{REFERENCES}

Anderson, B.R.O. (1991). Imagined Communities: Reflections on The Origin and Spread of Nationalism. London \& New York: Verso.

Asosiasi Museum Indonesia. (n.d.). Profil Museum di Seluruh Indonesia. Retrieved December 23, 2018, from http://asosiasimuseumindonesia.org/ anggota.html.

Balloffet, P., Courvoisier, F. H., \& Lagier, J. (2014). From Museum to Amusement Park: The Opportunities and Risks of Edutainment. International Journal of Arts Management, 16, (4), 4-18.

Bradburne, J. M. (2001). A New Strategic Approach to the Museum and its Relationship to Society. Museum Management and Curatorship, 19, (1), 75-84. https://doi.org/10.1080/09647770100701901.

Clifford, J. (1985). Objects and Selves: An Afterwords. In J.George W. Stocking (Ed.), Objects and Others: essay on Museums and Material Culture (pp. 236246). Wisconsin: The University of Wisconsin Press. https://doi.org/10.2307/j.ctv4cbhbg.41.

Crosby, N. (2016). In Search of Heterotopia : Immersive Experiences in the Museum. Master's Thesis Central Washington University.

Foucault, M., \& Miskowiec, J. (2012). Texts/ Contexts of Other Spaces. Diacritics, 16, (1), 22-27. Retrieved from https://www.jstor.org/stable/464648.

Geertz, C. (1992). Tafsir Kebudayaan. Yogyakarta: Kanisius.

Hall, S. (2003). The Work of Representation. In Stuart Hall (Ed.), Representation: Cultural Representation and Signifying Practices (pp. 1-11). London: Sage Publication.

Hooper-Greenhill, E. (1992). Museums and the Shaping of Knowledge. London \& New York: Routledge.

Jawa Timur Park Group. (2017, May 20). About Us: Transportasi Menembus Ruang Waktu. Retrieved March 19, 2018, from https://jtp.id/ museumangkut/profil.

Koentjaraningrat. (1980). Sejarah Teori Antropologi I. Jakarta: UI Press.

Kompas Travel. (2016, December 13). Libur Panjang, Jatim Park Group Dibanjiri Pengunung. Retrieved March 19, 2018, from https://travel.kompas.com/ $\mathrm{read} / 2016 / 12 / 13 / 193835527$ libur.panjang.jatim. park.group.dibanjiri.pengunjung.

Lidchi, H. (1997). The Poetics and The Politics of Exhibiting Other Cultures. In Stuart Hall (Ed.), Representation: Cultural Representation and Signifying Practices (pp. 151-208). London: Sage Publication.

Macdonald, S. J. (2003). Museums, National, Postnational and Transcultural Identities. Museum and Society, $1-16$.

Marsanto, K. (2012). Ekshibisi, Kekuasaan, dan Identitas: Tafsir atas Politik. Indonesian Journal of Social and Cultural Anthropology, 33, (1), 43-62.

McGregor, K. (2003). Representing the Indonesian Past: The National Monument History Museum from Guided Democracy to the New Order. Indonesia, 75 (April 2003), 91-122. Retrieved from http:// www.jstor.org/stable/3351309.

Metro Tv News. (2017, July 9). Pengunjung Museum Nasional Melonjak. Retrieved March19, 2018, from http://news.metrotvnews.com/ $\mathrm{read} / 2017 / 07 / 09 / 726673 /$ pengunjung-museumnasional-melonjak.

Milman, A. (2010). The Global Theme Park Industry. Worldwide Hospitality and Tourism Themes, 2, (3), 220-237. https://doi. org/10.1108/17554211011052177.

Munandar, A. ., Perdana, A., Andriyanti, R., Anissa, G., Asiarto, L., Supardi, N., Arbi, Y. (2011). Sejarah Permuseuman di Indonesia (Vol. 53). Jakarta: Direktorat Permuseuman, Direkorat Jenderal Sejarah dan Purbakala, Kementerian Pariwisata dan Ekonomi Kreatif.

Nuffida, N. E., Prijotomo, J., \& Rachmawati, M. (2016). Fenomena 'Entertainment Architecture' di Indonesia dan Perkembangan dalam Arsitektur. EMARA: Indonesian Journal of Architecture, 2, (2), 53-60. https://doi.org/10.29080/emara.v2i2.20. 
Rath, A. (1997). Cultural Sublimation: The Museuming og Indonesia. Journal of the Southeast Asian Studies Student Association, 1, (February), 1-22.

Rectanus, M.W. (2006). Globalization: Incorporating the Museum. In S.Macdonald (Ed.), $A$ Companion to Museum Studies (pp. 381-397). Oxford: Blackwell Publishing. https://doi. org/10.1002/9780470996836.

Svašek, M. (2007). Anthropology, Art and Cultural Production. London \& Ann Arbor: Pluto Press.

Taylor, P. M. (1995). Collecting Icons of Power and Identity: Transformation of Indonesian Material Culture in the Museum Context. Cultural Dynamics, 7, (1), 101-124. https://doi. org/10.1177/092137409500700105
Tribunnews Surya Malang. (2017, October 23). Museum Angkut Kota Batu raih penghargaan museum terbaik seindonesia, ini alasannya. Retrieved March19, 2018, from http://suryamalang. tribunnews.com/2017/10/23/museum-angkutkota-batu-raih-penghargaan-museum-terbaik-seindonesia-ini-alasannya.

Wardoyo, M., \& Zef, R. O. (2020). Open Museum As a Tool for Culture Sustainability: Prambanan Temple Study Case. Sosiohumaniora, 22, (1), 72-78. https://doi.org/10.24198/sosiohumaniora. v22i1.23786. 